\title{
HAS "YELLOW STRIPE" OR "MOTTLING" DISEASE ANY EFFECT ON THE SUGAR CONTENT OF CANE JUICE?
}

By F. A. Lopez Dominguez, Chief, Division of Chemistry.

Very early in the investigation of this disease the question arose as to its effect on the sugar content and purity of the juices of canes affected by it. From some quarters the claim was made that con siderable inversion occurred in the juices of diseased canes and that consequently there was a great loss of sucrose and that much trouble ensued in the process of manufacture, especially at the crystallizing pans and at the centrifuges. An investigation of the point raised was therefore necessary. An attempt was made to find literature containing data that would bear on the question but with no practical results. Only two references to the subject could be found: One in The Hawaiian Planter's Record, Vol. X, No. 5, page 321, where two analyses are given, one of healthy and the other of diseased canes, in which both samples show practically the same sugar content, while the diseased canes show a higher purity; the other is a general statement in the report on the disease by G. Wilbrink and F. Ledeboer of the Java Experiment Station, to the effect that canes from diseased seeds produced, in their experiments, an average of 17 per cent less sugar than canes from healthy seeds. There is no indication, however, to show whether this loss was due to a reduction in the sugar content of the canes or to a decrease in tonnage. It was necessary, therefore, to plan for an investigation of the subject.

Some preliminary work had been done, but of very little value, so far as a definite conclusion on the subject was concerned. Some samples had been submitted to this division for analysis by Mr. J. A. Stevenson, then pathologist at this Station, in July and November of 1917. Mr. E. D. Colón, at that time working on the disease for the Division of Pathology had performed a number of analyses on healthy and diseased canes, and in a number of instances samples had been sent from plantations to have comparative tests made. The results of the samples submitted by Mr. Stevenson have been already published in The Journal of the Department of Agriculture of PorTo Rico, Vol. IV, No. 1, for July 1919, pages 42 and 44, to which the reader is referred for details. Taken as a whole, these analyses did not lead to any practical conclusion, as no definite tendency was 
manifest, and the variations would oceur in all possible directions, regardless of the pathological condition of the plant.

A plan for a series of systematic analyses of healthy and diseased canes, that would eliminate as far as possible the variations due to the different factors that would bear on the results, was prepared by this division, in coöperation with the director, and the results obtained and the conclusions drawn from them are now presented in this paper.

The experiments were all performed at Central Bayaney, at Hatillo, whose board of directors extended their heartiest coöperation for the work, and did not spare any effort to help in every way possible to the success of the experiment. If everywhere the same spirit were shown, it would certainly be a pleasure to pursue lines of investigation which demanded coöperation of outsiders and many an agricultural problem would be more easily, cheaply, and wisely solved. In passing, I wish to extend $m y$ sincere thanks to the directors of Central Bayaney, and especially to the superintendent, Mr. Manuel Gorbea Pla, whose interest in the work did so much to overcome difficulties and make the work possible.

The analyses were performed on two different occasions: in May, 1919 , toward the end of the grinding season by the assistant chemist, Mr. Rafael Vilá Mayo, and in December of the same year at the opening of the 1920 campaign by the writer.

\section{PLAN OF THE EXPERIMENT.}

The play of the experiment was very simple. The basic idea was to make comparative analyses of healthy canes and canes in different stages of the disease growing under the same conditions, and showing as little individual differences between them as possible. The idea of taking separate samples of canes in different stages of the disease was suggested by previous work done on samples received from Central Cambalache. While working with these samples the writer noticed that marked differences were shown by the analyses of healthy canes and canes whose leaves were mottled but whose stalks were sound, on the one hand, and canes with cankered stalks on the other. Among the stalks which were cankered, some were badly cracked, and naturally, the idea suggested itself that the eracks in the stalks might be responsible for the differences observed. Accordingly, this point received due attention in the plan formulated. The following definite stages or manners of appearing of the disease were recognized: (1) canes whose leaves only were mot- 
tled, but whose stalks were perfectly sound; (2) canes whose leaves were mottled and whose stallss were striped and slightly depressed near the joints; (3) canes whose leaves were mottled, and whose stalks were badly cankered but showed no cracks; and (4) canes whose leaves were mottled and whose stalks were both badly eankered and cracked.

In Mr. Vilá's work two series of analyses were made. In the first, series $A$, parallel analyses were made of healthy cane, cane showing the mottling in the leaves only and canes with stalks badly cankered, but not cracked. For these analyses Rayada cane was exclusively used. In the second, series $B$, the comparison was made betreen healthy cane, cane with mottled leaves only, and canes with stalks cankered and cracked. For this series Cavangerie cane was used, as not enough Rayada canes could be found with eracks in the stallss. The samples were taken in groups of three, each sample in the group consisting of five canes. All samples in a given group were taken from stools standing as close together as possible, using canes in different stages of the disease from the same stool whenever feasible. The individual canes were selected so as to have all the uniformity allowed by the circumstances as to age, development and maturity. Comparisons, therefore, should be made between the different samples in the same group, and not between samples belonging to different groups. Each group was marked with a number and the letter of the series.

In the December work performed by the writer, four series of analyses were run: series $\mathrm{C}, \mathrm{D}, \mathrm{F}$, and $\mathrm{F}$. In these instances only two stages of the disease, instead of three, were compared at a time. Accordingly, groups of two samples each were taken and again five canes were allowed to each sample. All the precautions observed in the cutting of samples in the two previous series were carefully followed in taking these. As in this case only two samples were required for each group, it was possible to obtain them from the same stool, or from two adjacent stools more often, thus affording more opportunity for uniformity in the cane selected. Besides, only one class of canes, Rayada, was used in all the series, thus eliminating the possible element of variation due to varietal characteristics.

Series C was carried out with healthy canes, and canes which had the leaves only mottled. However, in groups $6-\mathrm{C}, 8-\mathrm{C}$ and $10-\mathrm{C}$, some stalks on the diseased samples were very slightly affected. The symptoms of the disease in these stalks were so slight that they were not thought to affect the results materially, and were preferred 
to others which were perfectly sound, for their close proximity to the corresponding healthy stalks in the groups. This cane came from a plantilla (plant eane) planting which was one of the most vigorous in the place.

The purpose of the next two series, $\mathrm{D}$ and $\mathrm{E}$, was to compare healthy canes with canes having mottled leaves and stalks visibly affected, but not cracked, and to see whether there was any difference in behavior between plant cane and ratoons. Accordingly, series D was run with plant canes, which had normal development, and were doing very well, and series $\mathrm{E}$ was run with samples from a field of fifth ratoons. In both cases the diseased canes showed striped, wrinkled internodes, depressed near the joints, and leaves heavily mottled. It is interesting to observe here that canes were found which, although having stalks in the condition just described, did not show any mottling in the leaves. Such canes were not included in the samples taken.

Series F. In this series canes with mottled leaves and sound stalks were compared with canes with stalks cankered and cracked. Although a fifth ratoon, the plantation was producing larger canes and more cane than any other in the place. The stalks were large and fully developed, and the stools had twelve to eighteen or twenty canes each. The plants with sound stalks taken had their leaves very heavily mottled, and most of the plantation was in this condition. The affected stalks were profusely striped, with a number of cracks running along the lower half of the stalk. Some of the internodes were very much depressed, but others were only mottled and cracked. It was hard, however to find stalks in this condition as the percentage of canes affected in this way was very low.

The samples were brought to the laboratory and immediately analyzed. The juice was expressed in a handmill by passing the cane twice through the mill, which gave an extraction ranging from 51 to 60 per cent. The juices were strained through a copper wire strainer and the following determinations performed on them: degree brix, sucrose, acidity, reducing sugars.

\section{METEODS OF ANALYSES.}

Brix.-Was determined as usually with the common brix spindle, the temperature of the juice taken, and the correction for temperature introdticed according to the table given by Spencer.

Sucrose--Sucrose was determined by the single polarization method of Horne's, using dry lead subacetate for clarification. The 
tables given by Spencer in the 1917 edition of his "Handbook for Cane-Sugar Manufacturers" were used for computing the sucrose from the polariscopic reading and the degree brix. The writer is aware of the fact that this method will not give the absolute per cent of sucrose in the juices, but it was thought to give sufficiently accurate results for comparative work.

Acidity.-It was intended to use logwood solution as indicator in the determination of acidity, but the reagent did not arrive in time for the spring work, so that Mr. Vila had to use litmus instead. It was found, by previous tests, that more concordant results between duplicates could be obtained by using the paper rather than the extract. Ten cubic centimeters of the juice were taken, diluted with about $50 \mathrm{cc}$ of distilled water, and $\mathrm{N} / 10$ sodium hydroxide solution run in until neutralization, as shown by the permanence of color of two strips of litmus paper, one red and the other blue, dipped in the solution. However, by December we already had the desired logwood extract, and this indicator was used in the succeeding series of experiments. Again 10 cc. of the juice were diluted with 50 ce. of distilled water, so as to make more perceptible the change in color of the solution. This indicator was found to give very satisfactory results. As shown in the tables, the acidity has been expressed as cubic centimeters of $N / 10$ alkali solution required to neutralize $100 \mathrm{ce}$. of juice.

Reducing sugars.-Under the limitations and lack of facilities in which this work was carried out the gravimetric method, which would have been preferred by the writer, could not be used. In looking for a volumetric method, accuracy and speed were the factors considered. The method had to be rapid enough to allow of a number of determinations being made by a single manipulator with very scant equipment, in a short time, as it was not desired to preserve juices for any length of time for this work. These determinations were to be made in fresh juice, as soon as possible after being expressed from the canes. Consider that only one alcohol lamp was available, and that consequently not more than one sample could be heated at a time. Duplicates were made of all determinations, and in some doubtful cases three and four determinations were made on a single sample.

Having all these conditions in mind the method of Schoorl de Hans was chosen. Accordingly, the following solutions and reagents were prepared:

1. Copper sulphate solution.-69.28 grams of chemically pure 
copper sulphate crystals were dissolved in 1 liter of distilled water. This solution was standardized against $N / 10$ sodium thiosulphate as explained below. 'The redueing' sugar equivalent of this solution was then determined by carrying out a test exactly as deseribed for the juires, excent that a standard solution of reducing sugar prepared by inverting c. p. sucrose was used.

2. Allicline lartrate solution.-Prepared by dissolving 346 grams of Rochelle salts and 100 grams of sodium of hydroxide per liter.

3. Tenth normal sodium thiosulphate solution.-A tenth normal solution of sodium thiosulphate was prepared, and titrated against a mixture of $5 \mathrm{ce}$ of the copper sulphate solution and 5 ce. of the alkaline tartrate after boiling for exactly two minutes and the addition of $20 \mathrm{ce}$. of 20 per cent potassium iodide sol., and $10 \mathrm{cc}$. of dilute sulphuric acid prepared as directed below. From this the equivalence of both solutions was found. All details given for the actual carrying out of the method with juices should be observed in this titration.

4. Potassium iodide solution.-A 20 per cent solution of potassium iodide solution was prepared.

5. Dilute sulphuric acid.-The solution was made by mixing equal volumes of chemically pure sulphuric acid sp. gr. 1.84 and distilled water.

Procedure.-Ten cubic centimeters of juice were diluted to a volume of $100 \mathrm{ce}$.

To ten eubic centimeters of the juice solution, 5 cc. of the copper sulphate solution and $5 \mathrm{cc}$. of the alkaline tartrate solution were added in an Erlenmeyer flask of about $300 \mathrm{ec}$. capacity. The flask was then quickly brought to boiling, and the boiling continued for exactly two minutes, at the end of which time the flask was suddenly brought under the tap and rapidly cooled to about $60^{\circ} \mathrm{C}$. Twenty cubic centimeters of the 20 per cent potassium iodide solution were then added, and then $10 \mathrm{ce}$. of dilute sulphuric acid. The copper sulphate not reduced by the juice was then immediately titrated with N/10 thiosulphate solution using starch as indicator, to a very pale or almost white color. From the number of cubic centineters of thiosulphate required for each eubic centimeter of copper sulphate solution as aiready determined, the volume of copper sulphate solution not reduced by the juice was calculated. This amount, subtracted from the $5 \mathrm{ce}$. of copper sulphate solution used, leaves the number of cubic centimeter's of copper sulphate solution reduced by the juice. From the reducing sugar equivalent of the copper sulphate solution 
the amount of reducing sugar in the 10 ce. of juice solution taken was found, and the percentage then calculated.

\section{RESULTS AND CONCLUSIONS.}

The results are presented below in tabular form and in graphs platted from the data given in each table, so that for each table there is a corresponding graph.

In plotting the curves only the data for sucrose, acidity and reducing sugars have been made use of, as these are the real dominant factors, and the inclusion of the degree brix and the purity would contribute nothing in this instance toward reaching a conclusion, while introducing more or less confusion in the diagrams.

As the purpose is to compare the condition of the samples in each group with one another rather than to compare results betweep different groups, the numbers of the groups were taken for abscisae and the percentage of sucrose and invert sugar, and the acidity expressed in cubic centimeters of $\mathrm{N} / 10$ caustic soda per 100 ce. of juice, for ordinates. It is clear, then, that there is no relation to be expected or found between ordinates and abscisae, and that the diagrams only purpose to show the comparison between the samples in each group irrespective of the other groups, by means of the relative positions of the corresponding points in each group. In other words, the results obtained for all samples in a given group appear represented by points in the same vertical line, and that line is marked at its foot on the horizontal designated "Base line" with the number corresponding to the given group. The points were placed by counting up from the base line the number of centimeters corresponding to the percentage which they intended to represent according to the scale given in each diagram for each group of lines. The points by themselves, then, would have been sufficient, hut they have been connected by lines as a help to the eye and to the imagination in establishing comparisons between the different positions.

Special attention should be called to the graphs plotted from Table II. Here some points appear which have not been connected by lines. The explanation is as follows: In groups 4 and 6 the samples corresponding to the mottled canes, and in group 5 the samples corresponding to the healthy cane, were lost, so that no figures appean for these in that table. No points appear in the graph for these corresponding positions. This left isolated the points corresponding to the samples of mottled cane in positions 5 and 7 , and they are shown by points surrounded by circles of red broken lines 
It will be noticed that, for the sake of contrast, the points on black lines are indicated by red circles, and the points in red lines by black circles. Where two concentric rings are seen as in the acidity curves at positions 1 and 2, it means that the points belonging to two different samples coincided. In these instances the acidity of the healthy and the mottled canes was exactly the same.

The horizontal straight lines mark the levels for the averages in each set of samples of canes affected to the same extent by the disease.

Table I-Series A.

COMPARATIVE ANALYSES OF HEALTHY CANES, CANES WITH THE IEAVES MOTTLETD AND SOUND STALKS, AND CANES WITH IEAVES MOTLED AND STALKS AFFECTED, BUT NOT CRACKED.

The different stages are distinguished in the table below by the terms "healthy," "mottled," and "cankered," respectively.

RAYADA-MAY 3 TO 10,1919

\begin{tabular}{|c|c|c|c|c|c|c|c|c|c|c|c|c|}
\hline \multirow[b]{2}{*}{ Group No. } & \multicolumn{3}{|c|}{ Brix } & \multicolumn{3}{|c|}{ Sucrose } & \multicolumn{3}{|c|}{ Purity } & \multicolumn{3}{|c|}{$\begin{array}{c}\text { Acidity Cubic cent. } \\
\text { N } / 10 \text { NaOH per } \\
100 \text { ce. Juice }\end{array}$} \\
\hline & 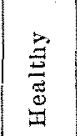 & $\begin{array}{l}0 \\
\frac{0}{3} \\
\underline{D} \\
0 \\
0\end{array}$ & 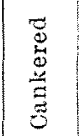 & $\underset{\underline{E}}{\stackrel{\vec{E}}{E}}$ & 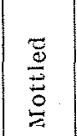 & 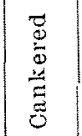 & $\underset{\Xi}{\stackrel{\Xi}{\Xi}}$ & 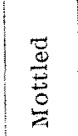 & 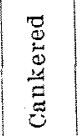 & 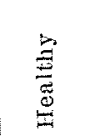 & $\frac{\frac{8}{8}}{\frac{3}{3}}$ & 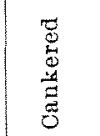 \\
\hline 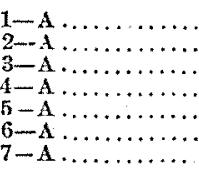 & $\begin{array}{l}19.00 \\
18.80 \\
18.20 \\
17.20 \\
17.40 \\
19.30 \\
18.40\end{array}$ & $\begin{array}{l}18.80 \\
18.70 \\
18.60 \\
17.60 \\
17.70 \\
18.60 \\
18.60\end{array}$ & $\left|\begin{array}{l}18.60 \\
18.30 \\
18.40 \\
17.00 \\
17.10 \\
18.50 \\
16.90\end{array}\right|$ & $\begin{array}{l}15.70 \\
17.00 \\
16.5 \\
15.51 \\
15.50 \\
17.08 \\
17.00\end{array}$ & $\begin{array}{l}16.00 \\
16.83 \\
16.78 \\
15.80 \\
16.80 \\
16.77 \\
16.76\end{array}$ & $\begin{array}{l}15.30 \\
15.90 \\
16.70 \\
15.70 \\
15.40 \\
15.70 \\
14.55\end{array}$ & $\begin{array}{l}81.60 \\
00.42 \\
90.66 \\
90.17 \\
89.08 \\
88.20 \\
92.40\end{array}$ & $\begin{array}{l}85.10 \\
90.00 \\
60.10 \\
90.34 \\
92.09 \\
90.20 \\
90.10\end{array}$ & $\left|\begin{array}{l}82.26 \\
86.89 \\
90.79 \\
92.94 \\
90.05 \\
84.90 \\
86.10\end{array}\right|$ & $\begin{array}{l}5.80 \mathrm{ce} \\
4.40 \\
5.60 \mathrm{cc} \\
1.80 \mathrm{ce} \\
1.40 \mathrm{ce} \\
3.50 \mathrm{ce} \\
3.80 \mathrm{ce}\end{array}$ & $\begin{array}{l}6.60 \mathrm{ce} \\
4.60 \mathrm{cc} \\
520 \mathrm{c} . \\
2.60 \mathrm{cc} \\
1.80 \mathrm{cc} \\
2.40 \mathrm{cc} \\
2.70 \mathrm{cc}\end{array}$ & $\begin{array}{l}7.20 \mathrm{cc} . \\
6.00 \mathrm{cc} . \\
5.20 \mathrm{ce} \\
4.80 \mathrm{ce} \\
4.60 \mathrm{ce} \\
5.80 \mathrm{ce} \\
4.50 \mathrm{ce} .\end{array}$ \\
\hline Averages... & 18.328 & 18.371 & 17.828 & 16.32 & $16.47 \%$ & $i^{15.607}$ & 89.014 & 89.690 & 87.542 & $3.685 \mathrm{cc}$ & $3.700 \mathrm{cc}$ & $5.442 \mathrm{cc}$ \\
\hline
\end{tabular}

On closely examining Table I, we find that by comparing the analyses of the different samples in the same group we do not discover any great discrepancies as regards the degree brix, the sucrose content and the purity of the juice. Out of seven groups analyzed in only four instances is there a decrease in the sucrose content of the cankered canes as compared with healthy canes, and in only three instances is the purity lower in the cankered than in the healthy canes. In only one instance is there a considerable difference in favor of the healthy canes, in group $7-\mathrm{A}$, in which the difference in sucrose reaches 2.45 per cent, and the purity is 6.3 points lower in the cankered cane. But this seems to be a case in which individual variations affected heavily the analysis of the sample, as it is the 


\section{Curves Plotted from Dato in Table I}

éy: Whole black lines show composition of healthy cane Ped lines " "cantered cane

Sucrose Curves

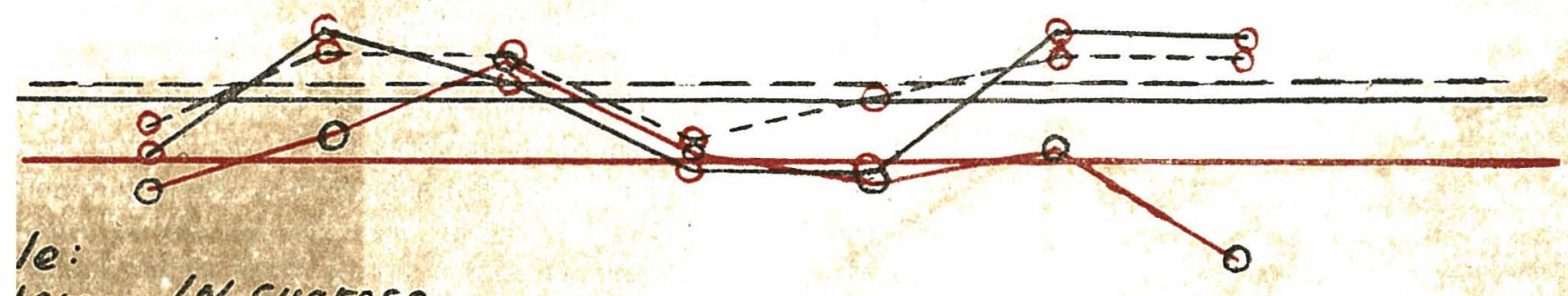

$\mathrm{cm}=1 \%$ sucrose

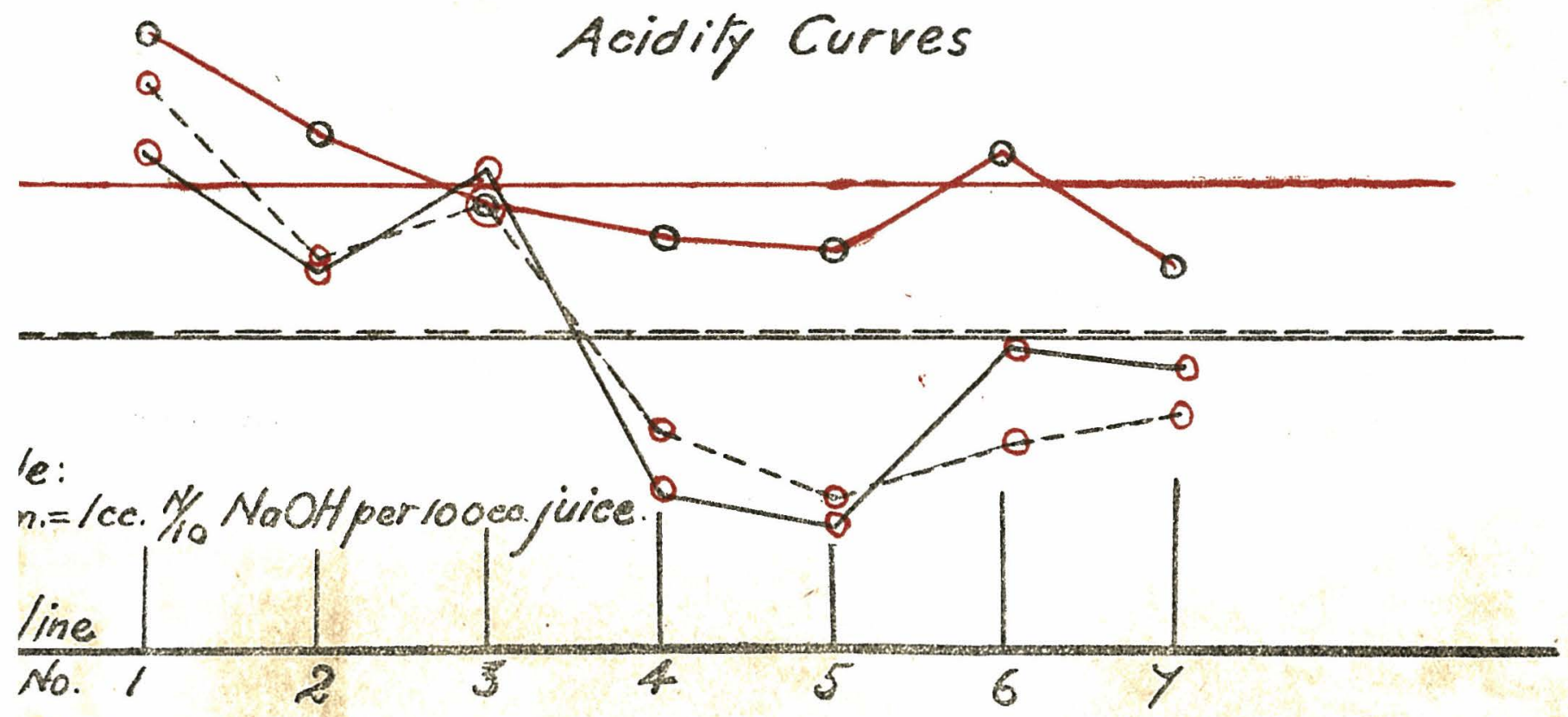


only instance in which such discrepancies are manifested. In two other cases only is the sucrose content of the cankered cane lower than that of the healthy cane by as much as 1 per cent. These are in groups 2 and 6 . Turning now to the averages, we find both suerose and purity lower in the cankered canes, but if the exceptional instance of group No. 7 is left out, these differences become too small to deserve consideration. Thus, averaging only the degree brix and the sucrose of the first six groups of cankered canes, and finding from the averages obtained the resulting purity, we get 17.983 for the brix, 15.783 for sucrose and 87.771 for purity. These will produce the differences of only 0.563 in sucrose and 1.273 in purity when compared with the averages of the samples of healthy canes.

An inspection of the sucrose curves constructed with these figures show these points very clearly. It will be noticed that only the ex. treme point to the right of the red curve falls at a considerable dis. tance below the corresponding point in the whole black line, and that only in two other cases at positions 2 and 6 show the corresponding points a noticeable difference in levels. In other eases the points in the red line are either a very short distance below, or slightly above those in the curve for healthy cane. It should be remembered that a distance of $1 \mathrm{~mm}$. in the diagram shows a dif. ference of only 0.1 per cent sucrose. The lines of averages, however, show a tendency toward a decrease on the part of the diseased cane, as mentioned in the discussion of the table. The conclusion seems warranted that the cankering of the stalk affects very little the sucrose content of the juice of diseased canes; or at least, that the extent to which it is affected would not be noticeable under factory conditions.

As for the cane having the leaves only mottled, a mere glance at the figures is enough to show that there is no difference between their juice and that of healthy canes. If anything, they seem to show up slightly better than the healty ones.

This is very well shown by the graph. As seen, the points in the curve for mottled cane appear in four instances above those in the same vertical line for healthy cane, while in the other three cases the points for the mottled are only very slightly below those for healthy cane in the same group. This shows no more variation than could be expected if duplicate samples of healthy canes only had been analysed. Notice that the line of averages for the mottled cane reaches a higher level than that for healthy cane, but that the dif- 
ference in levels is very little. It might as well have fallen below by about the same distance, for all we know.

With regard to acidity, the averages show that there is no difference between healthy and mottled cane, but cankered canes show a higher content, the excess being on the average equal to $1.757 \mathrm{cc}$. of $\mathrm{N} / 10$ caustic soda per 100 ce. of juice equivalent to 0.007028 gms. caustic soda in $100 \mathrm{ce}$ of juice. The curves for acidity as plotted from this table hardly need any comment. The coincidence of the two lines of averages corresponding to healthy and mottled cane as well as the relative positions of the corresponding points in the curves for these two classes of cane speak for themselves. The levels attained by the points in the curve for cankered cane as well as the line representing the average content show the greater acidity contained by these canes.

TMBLE II-SERIES B.

COMPARATIVE ANALYSES OF HEAITHY CANES, CANES WITH LEAVES MOTTLED AND SOUND STALKS, AND CANES WITH CANKERED, CRACKED STALKS.

The different stages are distinguished in the table below by the terms "healthy," " mottled," and "cankered," respectively.

OAVANGERTE-MLY 3 TO 10, 1919.

\begin{tabular}{|c|c|c|c|c|c|c|c|c|c|c|c|c|}
\hline \multirow[b]{2}{*}{ Group No. } & \multicolumn{3}{|c|}{ Brix } & \multicolumn{3}{|c|}{ Suerose } & \multicolumn{3}{|c|}{ Purity } & \multicolumn{3}{|c|}{$\begin{array}{c}\text { Acidiy. Cubic cent. } \\
N / 10 \text { NaOH per } \\
100 \text { cc. Juice }\end{array}$} \\
\hline & 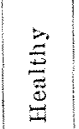 & 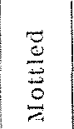 & 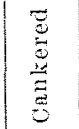 & 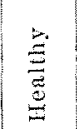 & 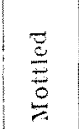 & 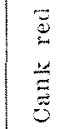 & 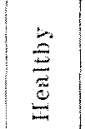 & 芯 & 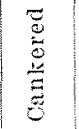 & 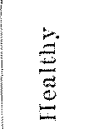 & 总 & 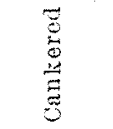 \\
\hline 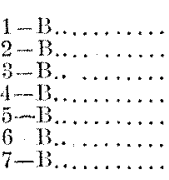 & $\begin{array}{l}18.60 \\
18.00 \\
18.20 \\
18.40 \\
18.80 \\
17.70\end{array}$ & $\begin{array}{l}17.90 \\
17.40 \\
18.20 \\
17.10 \\
13.40\end{array}$ & $\begin{array}{l}18.00 \\
14.90 \\
15.50 \\
15.40 \\
16.10 \\
16.60 \\
17.00\end{array}$ & $\begin{array}{l}16.16 \\
16.28 \\
16.40 \\
16.36 \\
16.714 \\
15.92\end{array}$ & $\begin{array}{l}16.00 \\
16.10 \\
16.78 \\
15.70 \\
15.48 \\
15.48\end{array}$ & $\begin{array}{l}15.25 \\
12.15 \\
11.90 \\
11.75 \\
11.15 \\
13.85 \\
14.44\end{array}$ & $\begin{array}{l}89.80 \\
90.44 \\
90.40 \\
48.96 \\
89.00 \\
00.00\end{array}$ & $\begin{array}{l}89.38 \\
92.59 \\
02.17 \\
91.81 \\
84.13\end{array}$ & $\begin{array}{l}81.72 \\
81.54 \\
76.77 \\
76.30 \\
75.46 \\
83.49 \\
85.00\end{array}$ & $\begin{array}{l}6.80 \mathrm{ce} \\
2.60 \mathrm{ce} \\
180 \mathrm{ce} \\
5.60 \mathrm{ce} \\
6.70 \mathrm{c} \\
2.80 \mathrm{ce}\end{array}$ & $\begin{array}{l}6.80 \mathrm{cec} \\
\text { o 60ce. } \\
8.700 \mathrm{c} \\
5.60 \mathrm{ce} \\
5.80 \mathrm{ce}\end{array}$ & 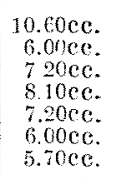 \\
\hline Averages... & 18.188 & 17.80 & 16.214 & 16.31 & 16.012 & 13.07 & 89.699 & 89,055 & 80.609 & $4.55 \mathrm{cc}$ & $4.900 \mathrm{c}$ & $7.257 \mathrm{ec}$. \\
\hline
\end{tabular}

Looking now at Table No. II, we find a very different state of affairs as regards the composition of the juices of cankered canes as compared with the juices of healthy canes. Here the difference is appurent at first sight. The degree brix, sucrose content, and purity, appear consistently lower in the cankered canes. In groups 2-B and $4-13$ the difference in sucrose reaches over 4 points, being 4.61 in the latter, while the average of all the differences is as high as 3.066 points. Taking the difference between the two sucrose averages 
(average for healthy cane, and average for cankered cane), we obtain a difference of 3.24 points in favor of the healthy cane. In purity we find differences as high as 12 and 13 points in groups 3-B and $4-\mathrm{B}$, the lowest difference being of 5 points, in group 7-B. Comparing the averages, we find a difference of 9.090 between the purity and healthy cane and that of cankered cane. The figures for the mottled cane again fail to show any appreciable differences with the healthy cane as regards sucrose and purity.

A slight gain in acidity is evidenced by the average of mottled canes compared with that of healthy canes, but as no consistency in the differences shown by the samples in the individual groups is apparent, no conclusion should be based on this fact. There is no question as to the higher acid content of the cankered canes. It should be noticed that the acidity in these canes is higher than that shown by the cankered canes in the previous series. Altough for reasons that could not be controlled at the moment a determination of reducing sugars could not be made in every case, yet those that were made consistently showed that considerable inversion occurred in the juices of canes whose stalks presented fissures as a result of the disease.

Notice now the curves plotted from the data in this table, (Table No. II). The sucrose and acidity curves for healthy and mottled cane follow pretty close one another and the differences between their lines of averages are not of much consequence. The fact that relative positions of the lines of average for sucrose (as regards healthy and "mottled" cane) are in this case the inverse of what they are in the previous graph, further justify our conclusion that the mere mottling of the leaves do not seem to affect the sucrose content of cane to any appreciable extent.

The curves for the cankered cane with eracked stalks, however, strikingly show the lower sugar content and higher acidity in these canes. It is well to notice that with the exception of the points in positions 1 and 2 , the points in the acidity curve attain higher levels and thcse in the sucrose curve appear at lower levels simultaneously, thus showing a corresponding decrease in sucrose whenever an increase in acidity is present. This correspondence will be further evidenced in the diagrams that follow. It is plain that this has been a clear case of fermentation due to the cracks in the rind of the cane.

The conclusion is irresistible that the cracking of the stalks causes inversion in the juices, with the consequent loss of sucrose. The higher acid content in these canes point to fermentation as the cause of this inversion. 
Reasoning from the results obtained in these series of analyses, the conclusion should be reached that the disease in itself does not affect to any appreciable extent the sucrose content in the juice, and that it is only when the stalks are cracked and fermentation ensues that a considerable decrease in the sucrose content results, as it would result in any other case in which a cane had sustained mechanical injury enough to cause the exposure of its inner tissues. At an advanced stage, the disease, however, seems to induce of itself an acid condition of the juice, but not to any considerable extent.

We shall see whether this thesis is sustained by the results obtained in the experiments that follow.

TABle III-SERIES C.

COMPARATIVE ANALYSES OF HEALTHY AND MOTTLED CANES.

The diseased eanes had only the leaves mottled.

PLANT CANE-DECEMBER 9, 1919.

\begin{tabular}{|c|c|c|c|c|c|c|c|c|c|c|}
\hline \multirow[b]{2}{*}{ Group No. } & \multicolumn{2}{|c|}{ Brix } & \multicolumn{2}{|c|}{ Sucrose } & \multicolumn{2}{|c|}{ Purity } & \multicolumn{2}{|c|}{$\begin{array}{c}\mathrm{Cu} \text {. Cent. of } \\
\mathrm{n} / 10 \mathrm{Na} \text { oH } \\
\text { per } 100 \mathrm{cc} . \\
\text { Juicee }\end{array}$} & \multicolumn{2}{|c|}{$\begin{array}{l}\text { Reducing } \\
\text { Sugars }\end{array}$} \\
\hline & 卷 & 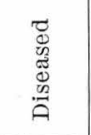 & 哭 & 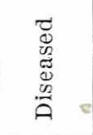 & 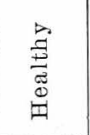 & 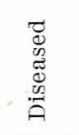 & 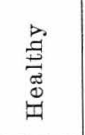 & 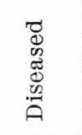 & 疍 & 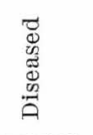 \\
\hline 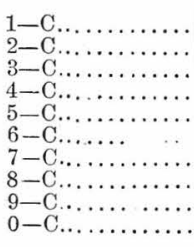 & $\begin{array}{l}17.47 \\
17.39 \\
16.87 \\
17.83 \\
14.59 \\
16.66 \\
17.16 \\
15.73 \\
17.56\end{array}$ & $\begin{array}{l}16.73 \\
15.31 \\
17.20 \\
17.29 \\
16.73 \\
15.23 \\
15.99 \\
16.26 \\
15.76 \\
17.56\end{array}$ & $\begin{array}{l}15.71 \\
16.65 \\
15.67 \\
16.80 \\
11.00 \\
14.12 \\
15.62 \\
12.52 \\
15.82\end{array}$ & $\begin{array}{l}15.13 \\
12.43 \\
15.71 \\
15.90 \\
15.52 \\
11.94 \\
13.85 \\
14.04 \\
12.57 \\
15.80\end{array}$ & $\begin{array}{l}89.92 \\
95.74 \\
92.88 \\
91.22 \\
75.39 \\
81.75 \\
91.02 \\
79.59 \\
90.09\end{array}$ & & $\begin{array}{l}2.50 \\
2.50 \\
4.00 \\
5.50 \\
3.00 \\
3.25 \\
4.00 \\
1.75 \\
2.00\end{array}$ & $\begin{array}{l}3.00 \\
2.50 \\
3.25 \\
5.25 \\
5.00 \\
8.50 \\
4.25 \\
3.75 \\
6.12 \\
4.00\end{array}$ & $\begin{array}{l}0.474 \\
0.428 \\
0.487 \\
0.323 \\
1.549 \\
1.067 \\
0.352 \\
1.131\end{array}$ & $\begin{array}{l}0.674 \% \\
1.444 \% \\
1.180 \% \\
0.284 \% \\
0.291 \% \\
1.251 \% \\
0.532 \% \\
0.261 \% \\
0.942 \% \\
0.359 \%\end{array}$ \\
\hline Averages..... & 16.806 & 16.406 & 14.879 & 14.289 & 88.534 & 87.09 & 3.166 & 4.562 & 0.726 & $0.722 \epsilon_{0}^{\prime}$ \\
\hline
\end{tabular}

An inspection of Table III will reveal the fact that no constant difference is introduced in the sugar content of the juices by canes attacked with the disease in which onty the leaves have become mottled. The differences between the samples in each individual group point sometimes one way and then another, while the averages come as close to each other as could be expected under the circumstances. Slight differences in averages, cannot be taken, of course, as the guiding principle in a work of this nature. It is only a reasonably consistent series of differences all pointing the same way what should be taken as an indication of a cause uniformly acting to produce a given effect. 
from Dala in Table III

canes.

ed canes

Sucrose Curves

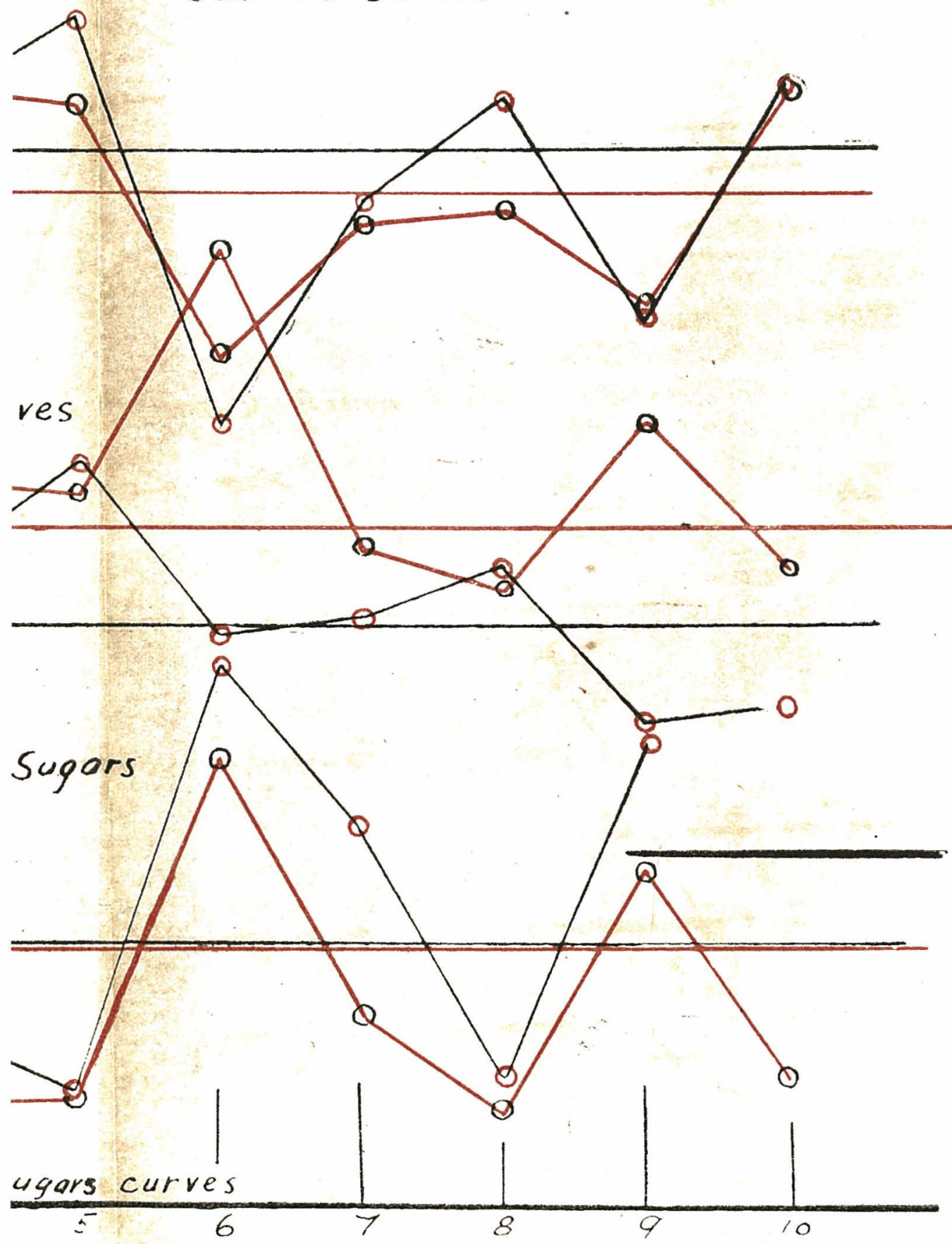


A study of the curves plotted from the data presented in this table will reveal very interesting points. Although judging from the lines of averages for reducing sugars there is no difference as between the healthy and diseased canes, and while only a small difference in favor of the healthy cane is shown by the sucrose curves, yet there is shown a higher acid content by the diseased canes. This increase in acidity is constant throughout all the series in which this factor has been included. It is further to be noticed here, as well as further on, that this difference, though constant, is very small in all cases except in very acute stages of the disease, reaching its maximum development only when the stalks crack. But this point may be better discussed after all the other tables and curves have been examined. For the present it is enough to notice that the extra acidity induced is not enough to cause inversion, as shown by the coindicence of the lines of averages for reducing sugar.

Table IV and $V$ show comparisons of healthy canes with canes which had mottled leaves and stalks depressed near the joints, but which showed no cracks or fissures in the stalks. In the first, plant cane was used, while in the second, ratoons were chosen. Both point to the same conclusion.

J'ABLE IV-SERIES D.

\section{COMPARATIVE ANALYSES OF MOTTLED AND HEALTHY CANES.}

The diseased canes in this series had the leaves mottled and the stalks affected but not cracked.

PLANT CANE-DECEMBER 17 TO 18, 1919.

\begin{tabular}{|c|c|c|c|c|c|c|}
\hline \multirow{2}{*}{ Group No. } & \multicolumn{2}{|c|}{ Brix } & \multicolumn{2}{|c|}{ Sucrose } & \multicolumn{2}{|c|}{ Purity } \\
\hline & Healthy & Mottled & Healthy & Mottled & Healthy & Mottled \\
\hline 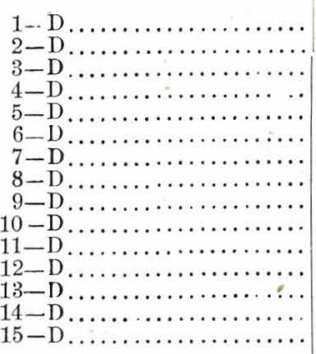 & $\begin{array}{l}(\mathrm{X}) \\
(\mathrm{X}) \\
16.03 \\
17.19 \\
14.73 \\
15.86 \\
16.39 \\
16.49 \\
15.93 \\
16.33 \\
16.19 \\
17.26 \\
14.96 \\
15.59 \\
16.79\end{array}$ & $\begin{array}{l}15.16 \\
15.49 \\
16.03 \\
15.89 \\
14.86 \\
16.03 \\
15.86 \\
16.39 \\
15.43 \\
15.93 \\
16.56 \\
16.59 \\
14.96 \\
14.96 \\
17.19\end{array}$ & $\begin{array}{c}\cdots \cdots \cdots \\
12.96 \\
14.58 \\
10.85 \\
12.79 \\
13.46 \\
13.56 \\
12.49 \\
12.99 \\
13.11 \\
14.01 \\
11.51 \\
12.71 \\
14.34\end{array}$ & $\begin{array}{l}12.56 \\
12.52 \\
13.21 \\
12.96 \\
12.42 \\
12.99 \\
13.26 \\
12.33 \\
12.28 \\
12.99 \\
13.84 \\
14.10 \\
12.10 \\
12.10 \\
14.96\end{array}$ & $\begin{array}{r}8 \cdots \cdots \\
84.84 \\
83.81 \\
73.66 \\
80.64 \\
82.12 \\
82.23 \\
78.38 \\
79.54 \\
80.79 \\
81.17 \\
76.93 \\
81.52 \\
85.00\end{array}$ & $\begin{array}{l}82.84 \\
80.82 \\
82.41 \\
81.56 \\
83.58 \\
81.03 \\
83.60 \\
75.22 \\
79.56 \\
81.54 \\
83.57 \\
84.99 \\
80.88 \\
80.88 \\
87.02\end{array}$ \\
\hline Averages........... & 16.134 & 15.822 & 13.027 & 12.914 & 80.742 & 81.620 \\
\hline
\end{tabular}

In Table IV, out of 13 instances in which a comparison could be estahlished in only 5 cases did the diseased cane show a lower sucrose 
content, and in only three cases was the purity of the diseased cane juices less than that of the healthy ones. The highest difference in sucrose in favor of the healthy canes was 1.62 points in group 4-D, in three other cases, groups $7-\mathrm{D}, 8-\mathrm{D}$ and $9-\mathrm{D}$, the difference was only of 0.20 to 0.23 points, and in group $14-\mathrm{D}$, of 0.61 . In the three cases of lower purities, the differences were 7.01 points in group 8-D, 3.35 points in group $4-D$, and 0.64 points in group $14-D$. In 10 instances out of 15 , and in 12 out of 15 , the sucrose content and purity were respectively higher in the diseased canes. These considerations more than counterbalance the slight differences shown in the arerages in favor of the healthy cane.

In Table $V$, the averages for the diseased and healthy canes show a wonderful agreement considering the circumstances. These figures hardly need any discussion; they speak clearly for themselves. There are no constant differences to speak of among the samples in each group or between the total averages obtained. Only in the case of the acidity seems there to be a tendency to show a slight constant difference pointing to an increase in the diseased canes. Tho differences, however, are very small.

\section{TABLE V-SERIES E.}

\section{COMPARATIVE ANALYSES OF MOTTLED AND HEALTHX CANES.}

The diseased canes had their leaves mottled and the stalks affected but not cracker.

RATOONS-DECEMBER 20 TO 22, 1919.

\begin{tabular}{|c|c|c|c|c|c|c|c|c|c|c|}
\hline \multirow[b]{2}{*}{ Gronp No. } & \multicolumn{2}{|c|}{ Brix } & \multicolumn{2}{|c|}{ Sucrose } & \multicolumn{2}{|c|}{ Purity } & \multicolumn{2}{|c|}{ Acidity } & \multicolumn{2}{|c|}{$\begin{array}{l}\text { Reduring } \\
\text { Sugars }\end{array}$} \\
\hline & $\begin{array}{l}\stackrel{\Xi}{\Xi} \\
\text { 总 }\end{array}$ & 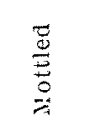 & 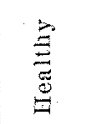 & 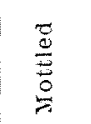 & 总 & 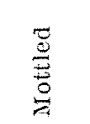 & $\stackrel{\vec{E}}{\stackrel{E}{E}}$ & 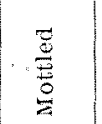 & 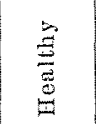 & 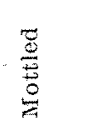 \\
\hline $\begin{array}{l}1-\mathrm{E} . \\
3-\mathrm{E} . \\
5-\mathrm{E} \\
6-\mathrm{E} \\
7-\mathrm{E} . \\
8-\mathrm{E} . \\
9-\mathrm{E} . \\
10-\mathrm{E} \\
11-\mathrm{E} \\
12-\mathrm{E} .\end{array}$ & $\begin{array}{l}17.89 \\
17.69 \\
17.19 \\
17.26 \\
15.06 \\
16.79 \\
13.56 \\
16.96 \\
17.06 \\
16.29\end{array}$ & $\begin{array}{l}17.49 \\
14.36 \\
15.29 \\
17.29 \\
16.56 \\
16.84 \\
17.39 \\
17.26 \\
15.56 \\
16.53\end{array}$ & $\begin{array}{l}15.85 \\
15.90 \\
15.42 \\
14.90 \\
12.40 \\
14.98 \\
10.50 \\
15.15 \\
14.32 \\
14.02\end{array}$ & $\begin{array}{l}15.15 \\
13.75 \\
12.52 \\
15.82 \\
13.81 \\
14.22 \\
15.36 \\
14.79 \\
12.79 \\
14.28\end{array}$ & $\begin{array}{l}88.59 \\
84.88 \\
89.70 \\
86.32 \\
82.38 \\
89.22 \\
77.43 \\
80.32 \\
83.98 \\
86.06\end{array}$ & $\begin{array}{l}86.62 \\
95.75 \\
81.88 \\
88.60 \\
83.89 \\
84.44 \\
88.82 \\
85.68 \\
82.19 \\
86.08\end{array}$ & $\begin{array}{l}2.25 \mathrm{cc} \\
1.75 \mathrm{cc} \\
2.50 \mathrm{cc} \\
1.75 \mathrm{cc} \\
3.00 \mathrm{cc} \\
2.50 \mathrm{cc} \\
2.75 \mathrm{cc} \\
2.50 \mathrm{cc} \\
2.50 \mathrm{cc} \\
1.75 \mathrm{cc}\end{array}$ & $\begin{array}{l}2.50 \mathrm{cc} \\
2.25 \mathrm{cc} \\
4.10 \mathrm{cc} \\
2 . .5 \mathrm{cc} \\
2.75 \mathrm{cc} \\
4.25 \mathrm{ce} \\
2.50 \mathrm{cc} \\
275 \mathrm{cc} \\
3.75 \mathrm{cc} \\
2.50 \mathrm{cc}\end{array}$ & $\begin{array}{l}0.766 \% \\
0.517 \% \\
0.8,2 \% \% \\
0.87 \% \\
0.805 \% \\
0.637 \% \\
1.625 \% \\
0.814 \\
1.24 \% \\
0.911 \%\end{array}$ & $\begin{array}{l}0.856 \% \\
1.03 \% \\
0.920 \% \\
0.38 \% \\
0.904 \% \\
0.814 \% \\
0.67 \% \\
0.880 \% \\
1.079 \% \\
0.830 \%\end{array}$ \\
\hline Averages... & 16.575 & 16.157 & 14.344 & 14.194 & 86.589 & 86.249 & $2.325 \mathrm{cc}$ & $2.960 \mathrm{cc}$ & 0.8712 & 0.8388 \\
\hline
\end{tabular}

These facts are more forcefully presented by the graphs corresponding to these tables. The sucrose curves plotted from Table IV 
ed from Dato in Table V

cane

d cane

e Curves
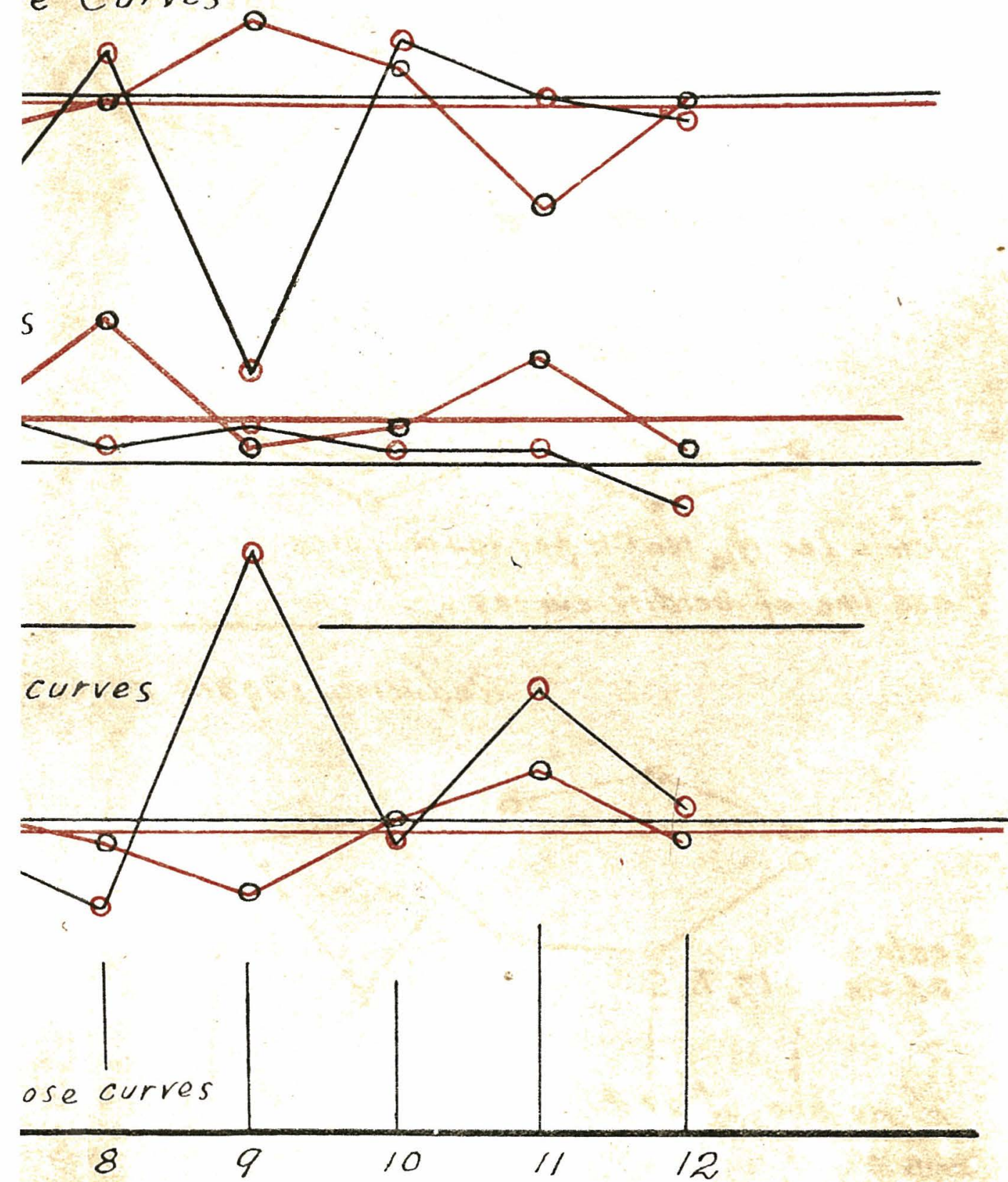
continually overlap, thus showing normal differences, as should be expected in different samples even of canes carefully selected to eliminate individual variations. There is not shown, or even suggested, a preponderance on the part of any of the sets of samples upon the other. The slight differences between the levels of the lines of averages in favor of the healthy cane cannot serve as the basis of a conclusion, in view of the lack of uniformity in the variations in the individual groups. The same comments apply with equal force to the sucrose and reducing sugar curves in Diagram V. Discussing further the curves plotted from Table $V$, we find again the increased acidity present in the diseased canes, in spite of the fact that the average for reducing sugars in these canes is slightly lower. Again this offers the suggestion that the slight increase in acidity has not been enough to cause inversion.

It should be noticed here as well as in the curves constructed from Table III that in fully 50 per cent of the cases compared the curves show an equal or lower glucose ratio for the diseased canes, a proof that the increase in acidity has not been enough to produce inversion. This may be seen by comparing the positions of corresponding points for sucrose and reducing sugars in each group of samples. Thus, in Graph III and referring to groups number 4, 6, 7 8 and 9 the distances from the base line to the points in the reducing sugar curve for diseased canes show a lower ratio to the distance from the base line to the points in the sucrose curve of these canes than the ratio shown by the distances indicated by the corresponding points in the curves for healthy eane. Remember that in only eight cases is this comparison possible as there were no reducing sugar determinations made in healthy cane groups 1 and 10. Refering now to Graph $V$ and groups number 6, 7, 9 and 10, the ratios between the distances from the base line to the points in the red curve for reducing sugars and the distances from the base line to the corresponding points in the red line for sucrose is lower than the ratios shown by corresponding pairs of points on the black curves for reducing sugars and sucrose, while in groups number 11 and 12 , these ratios are practically the same.

The two tables show rather conclusively that whether you take plant canes or ratoons the juice of the canes remain practically unaffected by the disease, (except for a slight increase in acidity noticeable in the juice of diseased canes), even when the stalks have become affected, provided that they preserve their rind whole, and no cracks have been formed. 
TABLE VI-SeRIES F.

COMPARATIVE ANAIYSES OF CANES IN AN ADVANCED STAGE OF THE MOTTLING DISEASE AND OF CANES SHOWING ONIY THE FIRST SYMPTOMS.

In the former the stalks were badly cankered, showing cracks at intervals, while in the latter only the leaves were mottled, the stalks being in good condition. In the following the terms "cankered" and "mottled only" will be used to distinguish between them. No glucose determinations were made for lack of reagents.

RATOONS.

\begin{tabular}{|c|c|c|c|c|c|c|}
\hline \multirow{2}{*}{ Group No. } & \multicolumn{2}{|c|}{ Brix } & \multicolumn{2}{|c|}{ Sucrose } & \multicolumn{2}{|c|}{ Purity } \\
\hline & Cankered & $\begin{array}{l}\text { Nottled } \\
\text { only }\end{array}$ & Cankered & $\begin{array}{l}\text { Mottled } \\
\text { only }\end{array}$ & Cankered & $\begin{array}{l}\text { Motiled } \\
\text { only }\end{array}$ \\
\hline 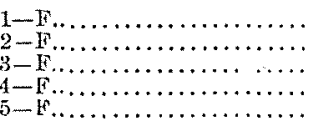 & $\begin{array}{l}13.79 \\
18.71 \\
14.86 \\
17.13 \\
1.79\end{array}$ & $\begin{array}{l}17.39 \\
16.89 \\
17.56 \\
17.28 \\
15.89\end{array}$ & $\begin{array}{r}9.74 \\
17.34 \\
11.78 \\
15.42 \\
1050\end{array}$ & $\begin{array}{l}15.76 \\
15.07 \\
16.05 \\
14.97 \\
13.30\end{array}$ & $\begin{array}{l}70.69 \\
92.67 \\
79.27 \\
90.00 \\
76.14\end{array}$ & $\begin{array}{l}90.62 \\
89.21 \\
91.40 \\
86.88 \\
83.70\end{array}$ \\
\hline Averages............. & 15.656 & 16.992 & 12.956 & 15.020 & 82.766 & 88.453 \\
\hline
\end{tabular}

Table VI affords an opportunity of comparing diseased canes with fissures in their stalks, with mottled canes having sound stalks. The differences again stand out clearly showing the effect of the sracks. It should be observed that aside of the cracks and the stripes shown by the stalks, these canes were well developed, and that in some of the samples the cracks were more numerous than in others. This accounts for the good showing made by two of the samples. The averages, besides, show appreciable differences. It is to be regretted that more samples of this type could not be secured, but the time available for the work was short, and searching for the few scattered samples of this sort that could be obtained in the place proved to be a time-consuming operation.

The curves plotted to represent the variations shown by this table hardly need any more comment than what has been said in connection with the table itself. The difference between the lines of averages is enough to point out the direction in which the changes occur. In the samples where the number of cracks was noticeable the difference in sucrose is striking, as shown by points in positions. 1, 3 and 5 . The two points showing a high sucrose content serve as further proof of the conclusion reached, as thev were the samples with only a small number of cracks. 
Hed from Data in Table VI

Sucrose Curves

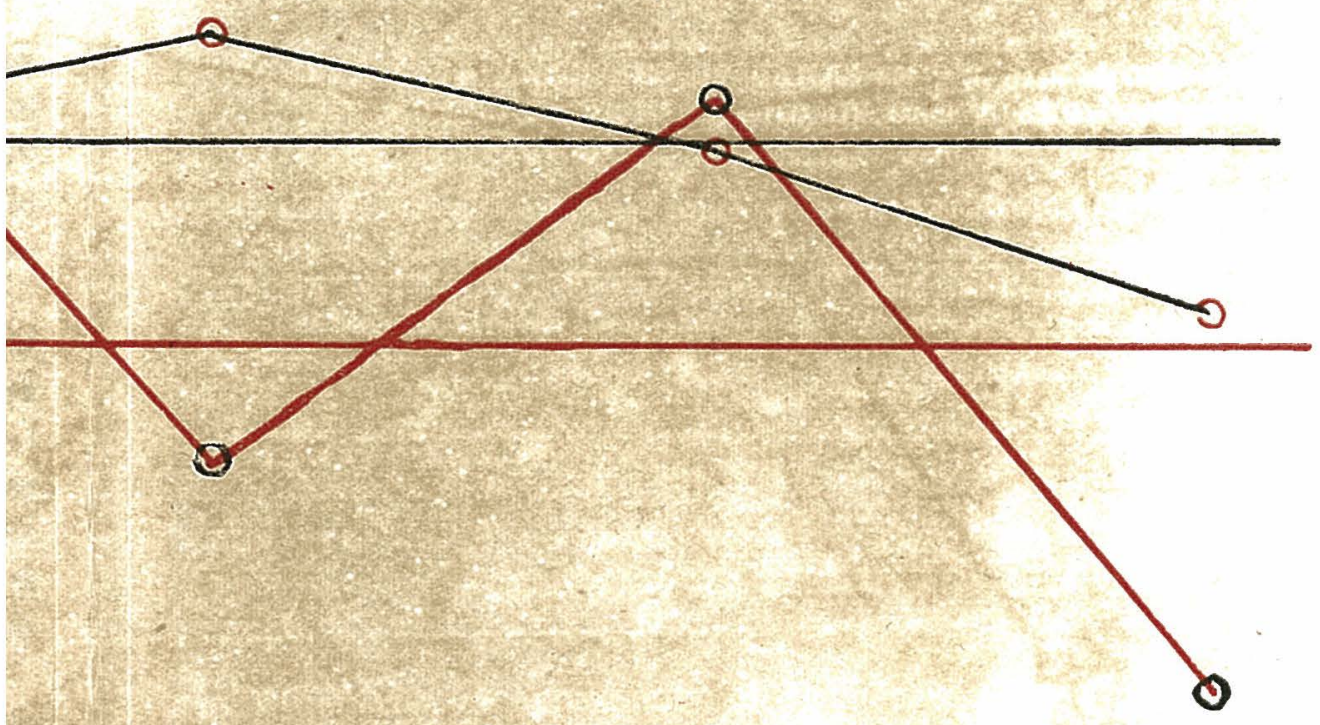

of healthy cane

- cankered cane

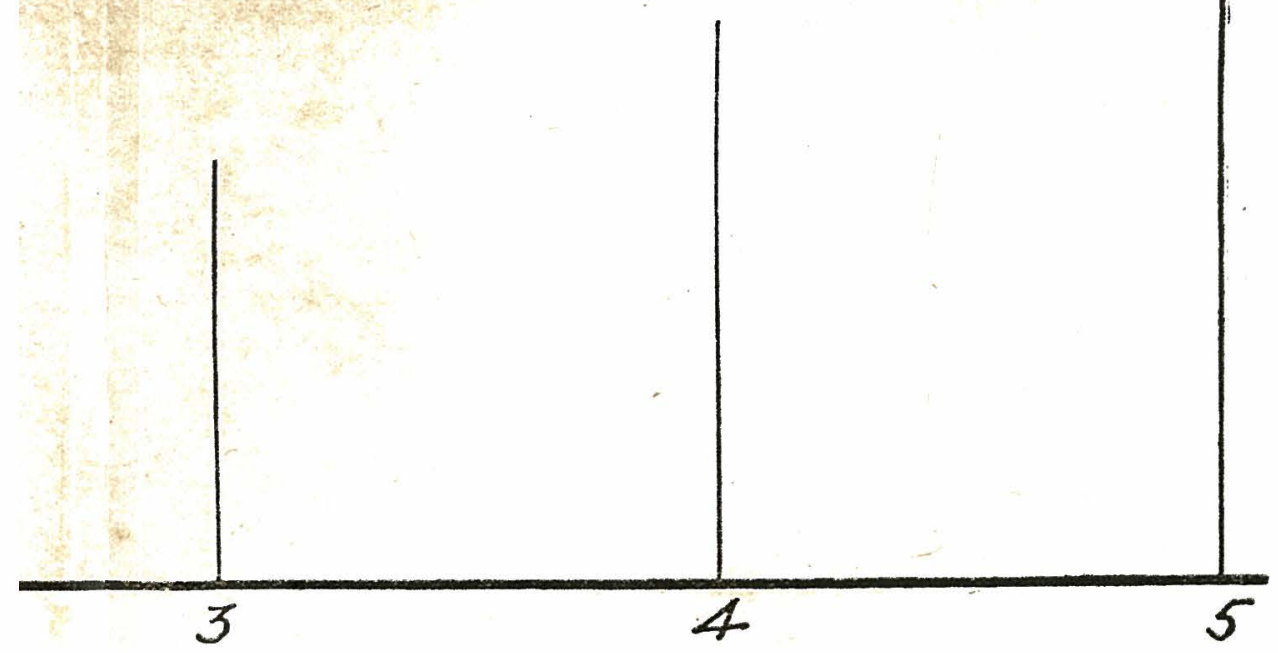


The results, further more, corroborate those obtained by Mr. Vilá, and shown in Table II.

\section{SUMMARY.}

1. Parallel analyses of healthy cane, cane with mottled leaves, and canes with leaves mottled and stalks affected by the disease but not cracked, conducted during the spring of 1919, failed to show any difference in the sugar content of the canes compared. A slight gain in acidity was observed on the part of the cankered canes. The canes used were of the Rayada variety.

2. A second series of parallel analyses using Cavengerie cane and substituting canes with the stalks cracked for the cankered canes with the stalks whole revealed higher acidity, lower sucrose content, and in the cases where tests were made, a higher content of reducing sugars in the cankered, cracked canes. No differences that deserve mention were noticed on comparing the canes with mottled leaves with the healthy ones, except for a slight tendency toward a higher acid content shown by the former.

3. Comparisons between healthy canes and canes with leaves mottled but unaffected stalks conducted in December, 1919, did not show any constant differences in sucrose, or reducing sugars, but again the increased acid content of the mottled canes, though small was noticeable.

4. Comparative analyses of diseased canes having their stalks affected, but not cracked, with healthy canes, using both plant cane and ratoons performed in December, failed again to show any appreciable differences in their juice composition as regards sugar content; the acidity, however, showed a slight increase in the diseased cane.

5. A series of experiments conducted to compare diseased, cankered canes having the stalks cracked, with diseased canes having sound stalks showed lower sucrose content and lower purity in the former.

\section{CONCLUSION.}

The general conclusion is forced by the facts as revealed by these series of analyses that the mottling or yellow-stripe disease does not affect materially the sugar content of the juice of canes attacked with the disease, except in an indirect way, when the stalks become cracked as a result of the drying up of the stalk. In this case the 
exposure of the inner tissues brings about fermentation, as in the case of any other mechanical injury received by the stalk bad enough to cause cracking of the rind, with the subsequent increase of acidity, inversion, and loss of sucrose. There is, however, a tendency on the part of diseased canes to show an increase in the acid content of the juices, but this increase is not serious enough to cause inversion, except in very acute stages of the disease, and after the stalks have become cracked as a result of being badly cankered. 